\title{
Expressing religious identities in the workplace: Analyzing a neglected diversity dimension
}

human relations

\section{Diether Gebert}

Renmin University of China, China

\section{Sabine Boerner}

University of Konstanz, Germany

\section{Eric Kearney}

Leibniz Universität Hannover, Germany

\section{James E King Jr}

University of Alabama, USA

\section{Kai Zhang}

Renmin University of China, China

\section{Lynda Jiwen Song}

Renmin University of China, China

\begin{abstract}
Responding to Jackson and Joshi's (20II) call for specific models of the effects of particular diversity types and against the backdrop of the rising desire for the public expression of religious identities in the workplace (Hicks, 2003), we develop a framework that systematically explores when and how the expression of diverse religious identities induces relational conflicts in organizational units. In developing this framework, we integrate the respective literatures on religion studies (e.g. Hicks,
\end{abstract}

\section{Corresponding author:}

Lynda Jiwen Song, School of Business, Renmin University of China, Beijing, China.

Email: songjiwen@gmail.com 
2003), identity-disclosure (e.g. Ragins, 2008) and diversity within organizational groups (Jackson and Joshi, 20l I). Our framework specifies three paths whereby the public expression of diverse religious identities can engender relational conflicts. As mediators, we discuss perceivers' attribution of proselytism and religious discrimination, as well as identity threats. Moreover, we examine the moderating roles of actors' and perceivers' religious fundamentalism, perceivers' religious identity salience and minority members' attribution of majority members' religious hegemonial claims. At the theoretical level, we delineate particularities of religious identity diversity that distinguish this diversity type from other deep-level diversity attributes. Concerning practical implications, we argue that it is important to not only foster self-expression, but also to be cognizant of the risks that the public expression of religious identities entails.

\section{Keywords}

diversity research, identity threat, proselytism, relationship conflicts, religious discrimination, religious diversity, religious fundamentalism

Increasing diversity in the workplace (Jackson and Joshi, 2011) constitutes a challenge for many organizations (Cash and Gray, 2000). Diversity refers to the extent to which members of an organizational unit are dissimilar from one another in one or more attributes, as well as the distribution of these attributes within the respective unit (e.g. Harrison and Klein, 2007; Williams and O'Reilly, 1998). Concerning diversity research, thus far, first, workplace diversity has been researched predominantly conducted with respect to demographic diversity variables such as gender, age, race/ethnicity (e.g. Joshi and Roh, 2009) - so-called surface-level diversity variables, which are easily observable. A much smaller number of studies has examined the effects of deep-level diversity variables such as attitudes, beliefs and values, defined as not directly observable (Harrison and Klein, 2007; Harrison et al., 1998). Second, in their review article, Jackson and Joshi (2011) call for more studies on when and how different types of diversity have differential effects on processes in organizations. Addressing these two issues, we explore the effects of diversity of religion-related beliefs and values on processes in organizations, thereby focusing on a deep-level diversity variable that has received practically no attention in the extant diversity literature.

At the societal level, tensions among members of different religions are frequent causes of conflict, occasionally resulting in violence (Wuthnow, 2007). It is therefore surprising that organizational scholars have thus by and large ignored the question of when and how diverse religion-related beliefs and values engender relational conflicts (Exline and Bright, 2011; King, 2008). At the same time, diversity concerning religionrelated beliefs and values is increasing in the USA (Wuthnow, 2004) and therefore presumbly also in the workforce of many, if not most, organizations. Moreover, there is a rising desire on the part of employees to express their religion publicly, including in the workplace (e.g. Lips-Wiersma and Mills, 2002). 
Against this backdrop, the present article analyzes the link between the public expression of diverse religious identities and relational conflicts within organizational units. The public expression of religious identity pertains to how employees make their religion and its attendant beliefs and moral values apparent, either verbally (e.g. in statements or discussions) or through religious rituals (e.g. praying, wearing religious clothes) or actions (e.g. displaying religious objects at work, inviting colleagues to religious events). Relational conflicts (relationship conflicts) refer to emotional tensions among persons that manifest either in heated debates or in the tendency to avoid one another (Jehn and Bendersky, 2003). A large body of literature has shown that relational conflicts are consistently negatively related to synergistic cooperation and group performance (e.g. De Wit et al., 2012).

According to social identity theory (e.g. Tajfel and Turner, 1986), a person's social identity is based on his or her membership in social collectives. Insofar as an individual's religious identity is tied to membership in a religious denomination (Hill et al., 2000), religious identity is thus a part of the respective person's social identity. The religious identity of a person pertains to the central beliefs of that person's religion (e.g. the existence of a benevolent God), as well as its moral values (e.g. to help people in need) (Blogowska and Saroglou, 2011; Hill et al., 2000).

Given that central beliefs and moral values are not directly visible, religious identity, as mentioned, constitutes a deep-level diversity (see Harrison et al., 1998). However, classifying religious identity as a deep-level attribute may be problematic in some cases. For some believers, visible signs of their membership in a particular religion (e.g. specific styles of dressing, skin markings) constitute an integral part of their religious identity (Hicks, 2003). In such cases, religious identity can no longer be viewed as a deep-level variable, because deep-level and surface-level attributes are inseparably connected in the religious identities of these believers whose outward appearance clearly exposes their deep-level religious identity. Nevertheless, this constellation is likely to be atypical for the overwhelming majority of the religious denominations in the US context that we focus on (see Table 1).

For most individuals, therefore, the public expression of diverse religion-related beliefs constitutes a disclosure of an otherwise invisible identity. Hence, in developing our model, we draw on the literature that examines such disclosures (e.g. Ragins, 2008). The growing need to express one's religious identity in the workplace (e.g. Miller, 2007) may reflect a person's desire for self-verification and to act in accord with his or her ideal self through the alignment of thought and action in all spheres of life (Lips-Wiersma and Mills, 2002; but also see Chaves, 2010). This may reflect a high religious identity salience, which describes the centrality of a social identity across a person's multiple social identities (Petriglieri, 2011). For many believers, their religious identity salience is high, given that religion constitutes a basic orientation with respect to many important questions in life, as well as a metaphysical orientation that extends the believer's secular existence (Weaver and Agle, 2002).

Within the context of an organization in which diverse religious beliefs and moral values are represented, a public expression of religious identity may imply the disclosure of a stigmatized identity - as was the case, for example, for Muslims in the USA after 9-11 (Ragins, 2008). Such a public expression therefore reflects the decision of a person 
Table I. Self-described religious identification of adult population from 2012 statistical abstract of the US Census Bureau.'

American Religious Identification Survey (ARIS) 2008

\begin{tabular}{lrr}
\hline Religious tradition & Estimate & Percentage (\%) \\
\hline Catholic & $57,199,000$ & 25.1 \\
Baptist & $36,148,000$ & 15.8 \\
Mainline Christian & $29,375,000$ & 12.9 \\
Christian (generic) & $32,441,000$ & 14.2 \\
Pentecostal/Charismatic & $7,948,000$ & 3.5 \\
Protestant denominations & $7,131,000$ & 3.1 \\
Mormon/ Latter Day Saints & $3,158,000$ & 1.4 \\
Jewish* & $2,680,000$ & 1.2 \\
Eastern religions & $1,961,000$ & 0.9 \\
Muslim & $1,439,000$ & 0.6 \\
NRMs \& other religions & $2,804,000$ & 1.2 \\
None/ No religion & $34,169,000$ & 15.0 \\
DK/ Refused & $11,815,000$ & 5.2 \\
Total & $228,268,000$ & 100
\end{tabular}

American Religious Identification Survey (ARIS) 2008

\begin{tabular}{lccc}
\hline & Estimate & \% of subcategory & \% of total \\
\hline Mainline Christian & $29,375,000$ & 100 & 12.9 \\
Methodist & $11,366,000$ & 38.7 & 5.0 \\
Lutheran & $8,674,000$ & 29.5 & 3.8 \\
Presbyterian & $4,723,000$ & 16.1 & 2.1 \\
Episcopalian/Anglican & $2,405,000$ & 8.2 & 1.1 \\
United Church of Christ & 736,000 & 2.5 & 0.3 \\
Other & $1,471,000$ & 5 & 0.6 \\
Christian generic & $32,441,000$ & 100 & 14.2 \\
Christian unspecified & $16,834,000$ & 51.9 & 7.4 \\
Non-denominational & $8,032,000$ & 24.8 & 3.5 \\
Protestant unspecified & $5,187,000$ & 16 & 2.3 \\
Evangelical/Born Again & $2,154,000$ & 6.6 & 0.9 \\
Other & 234,000 & 0.7 & 0.1 \\
Pentecostal/Charismatic & $7,948,000$ & 100 & 3.5 \\
Pentecostal unspecified & $5,416,000$ & 68.1 & 2.4 \\
Assemblies of God & 810,000 & 10.2 & 0.4 \\
Church of God & 663,000 & 8.4 & 0.3 \\
Other & $1,059,000$ & 1.3 & 0.4 \\
Protestant denominations & $7,131,000$ & 100 & 3.1 \\
Churches of Christ & $1,921,000$ & 26.9 & 0.8 \\
Jehovah's Witness & $1,914,000$ & 26.8 & 0.8 \\
Seventh Day Adventist & 938,000 & 13.2 & 0.4 \\
Other & $2,358,000$ & 33.1 & 1.1 \\
\hline
\end{tabular}


Table I. (Continued)

American Religious Identification Survey (ARIS) 2008

\begin{tabular}{lccc}
\hline & Estimate & \% of subcategory & \% of total \\
\hline Eastern religion & $1,961,000$ & 100 & 0.9 \\
Buddhist & $1,189,000$ & 60.6 & 0.5 \\
Other & 772,000 & 39.4 & 0.4 \\
Nones/No religion & $34,169,000$ & 100 & 15.0 \\
Agnostic & $1,985,000$ & 5.8 & 0.9 \\
Atheist & $1,621,000$ & 4.7 & 0.7 \\
Other & $30,563,000$ & 89.5 & 13.4 \\
\hline
\end{tabular}

'Available at: http://www.census.gov/compendia/statab/cats/population/religion.html (accessed I4 November 20I2).

*This refers to Jews by religion and not to the total Jewish ethnic population.

not to hide, but to reveal an otherwise invisible identity (Clair et al., 2005). Ragins (2008) developed a model that specifies the antecedents as well as the consequences of such a decision for the respective person. By contrast, the framework we propose here addresses the consequences of such decisions to publicly express an otherwise invisible identity for the respective organizational unit. Moreover, we explore the conditions under which these consequences are more or less likely to ensue. Unlike Ragins (2008), we do not focus on the disclosure of one's sexual orientation, but instead one's religious identity.

We assume that the public expression of the actor will tend to be interpreted by the perceivers as being the result of the actor's personal decision - that is, a conscious and voluntary act. The literature on fundamental attribution errors (i.e. the widespread tendency to attribute the causes of behavior to the person rather than the situation, even when this is inaccurate (Ross, 1977)) suggests that this is likely to be the case even when actors do not believe themselves to be free to choose whether or not to express their religious identity - for example, when their respective religion demands it. The fact that not all members of a given religion choose to adhere to all prescribed behaviors makes it even more likely that perceivers will regard public expressions as voluntary.

Hence, in this article we explore a previously unexamined form of deep-level diversity whose public expression can trigger specific attributions on the part of perceivers (e.g. that the actor is proselytizing - that is, attempting to convert or recruit others) because perceivers may wonder why the actor chooses to make his or her religious identity known. This question regarding the reasons for other people's behaviors is of little relevance in the context of diversity types such as heterogeneity with respect to taskrelated knowledge, because the public display of such attributes is typically perceived as more or less directly tied to working on the tasks at hand. By contrast, this question is highly relevant with respect to the deep-level diversity type 'religious identity' because, consistent with historical US culture and practice (Cash and Gray, 2000; Morgan, 2005), the public expression of religious identity might violate US workplace norms in secular organizations (Cash and Gray, 2000). Accordingly, some believers feel that the public expression of religious identity 'seems out of place' at work (e.g. Lips-Wiersma and Mills, 2002: 191). We argue that, if perceivers attribute proselytizing intentions to actors, relational conflicts are particularly likely to ensue. 
We propose that there are important differences with respect to the way in which different deep-level diversities are related to relational conflicts. These differences pertain to the extent to which the expression of these variables - from the perspective of both actors and perceivers - is under the control of the actors. For example, the expression of personality traits (e.g. extroversion, timidity, closed-mindedness), which also may engender relational conflicts, may mainly be interpreted as being determined by genes and long-term socialization processes. By contrast, expressing one's religious identity may to a larger extent be interpreted as a voluntarily decision of the actor.

Even if the effects of such an expression are the same (that is, relational conflicts), this distinction is important. If deep-level diversity exists with regard to personality traits, one could prevent conflicts by, for example, taking personality into account when assembling the team (Humphrey et al., 2007). In the case of religious diversity, by contrast, conflicts may be prevented by coaching (1) actors concerning how to express their religious identities and (2) perceivers how to interpret actors' expression of religious identities (see King EB et al., 2010) and by establishing within the organizational culture certain norms in this regard (Ragins, 2008).

Hence, by examining the public expression of diverse religious identities, we focus on a deep-level diversity type that may engender relational conflicts that did not exist prior to this expression. As a practical consequence, it is sensible to ask whether organizations could in some way benefit from permitting latent deep-level diversity attributes (religious identities) to become visible or whether such public expressions will predominantly engender negative effects.

There is empirical evidence for the assumption that public expression of diverse religious identities in the workplace can indeed foster interpersonal tensions (King JE et al., 2010; Mitroff and Denton, 1999). Relational conflicts caused by the public expression of religious identities can impair synergistic collaboration and performance (De Wit et al., 2012). To simplify our framework, we focus on the links between the public expression of diverse religious identities and relational conflicts, not on the consequences of relational conflicts, which a large body of literature has shown to be negative with respect to a wide range of outcomes (De Wit et al., 2012).

Some authors view the public expression of diverse religious beliefs more favorably (e.g. Gentile, 2011; Hicks, 2003; Miller, 2007), whereas others are more skeptical (e.g. Morgan, 2005). To explain and reconcile these opposing views, we discuss the risks and the potential benefits associated with such an expression, as well as the moderators that determine whether the former or the latter will prevail.

The present article makes several important contributions to the diversity literature. First, whereas some studies have examined deep-level attributes such as personality traits and task-related knowledge (e.g. Kearney et al., 2009), research on diversity concerning religious identities remains scarce (King, 2008). Against the backdrop of the rising need and demand for the public expression of religious identities (Hicks, 2003), we develop a framework that examines when and how such an expression can induce relational conflicts and thus impair outcomes in organizational units. In doing so, we respond to Jackson and Joshi's (2011) call for specific frameworks that address the particularities of specific (deep-level) diversity attributes. 
Second, our framework helps to establish the missing link (Stevens et al., 2008) between religious studies (e.g. Lynn et al., 2010) and identity-disclosure research (e.g. Ragins, 2008) on the one hand and management-oriented diversity research (e.g. Jackson and Joshi, 2011) on the other. From the perspective of the literature on the disclosure of invisible identites (Clair et al., 2005), it is reasonable to assume that the public expression of religious identities in secular organizations - thereby violating culture norms in the US context (Cash and Gray, 2000) - will be interpreted as the actors' voluntary decision, thus fostering (dysfunctional) attributions of intentions on the part of the perceiver. Such attributions have thus far not been considered as an explanation for relational conflicts.

Third, instead of explaining relational conflicts primarily as a result of social categorization processes (e.g. Van Knippenberg et al., 2007), we discuss the alternative mediators: attribution of proselytism and attribution of religious discrimination. This more complex explanatory model offers a more fine-grained analysis of the benefits and risks associated with the public expression of diverse religious identities.

\section{Focus on the US context}

In examining the advantages and drawbacks entailed by the public expression of diverse religious identities, we focus on the US context, because in the USA both religious diversity (Wuthnow, 2007) and religious identity salience are high (Stark and Glock, 2008). Table 1 delineates religious diversity (defined as the number and distribution of different religious denominations within a social collective) at the societal level. Moreover, the high identity salience of religion is reflected in rising efforts to proselytize on the part of some Pentecostal denominations (Roy, 2011), as well as in the so-called 'faith-at-work movement' (Miller, 2003). The faith-at-work movement is a decentralized initiative that in 2003 already comprised 1200 different religious groupings in the USA (Miller, 2003). Among these are mainline, liberal and Pentecostal Protestants, but also Catholics, Jews, Buddhists and Muslims (Miller, 2007). Their common goal is the unfettered expression of faith, and in some cases proselytism, in the workplace (Miller, 2003).

\section{Legal context}

US law (for an overview see Gregory, 2011) prohibits restrictions on the practice of religion (42 U.S.C. Paragraph 2000 e-2, 1994). Nevertheless, US organizations have some leeway in that they are merely required to make 'reasonable' accommodations (Cash and Gray, 2000). They can, for instance, constrain the public expression of religion by citing 'undue hardships' (42 U.S.C. Paragraph 2000 e(j), 1994). Such 'undue hardships' may exist, for example, when the religion-related absence of an employee results in disadvantages for other employees, as may be the case when the necessary workflow gets interrupted. It is this leeway in combination with unclear criteria with regard to 'reasonable' accomodations and 'undue hardships' (Cash and Gray, 2000) that not only gives rise to court battles and societal discussions, but also conflict-laden debates within organizations (Morgan, 2005) that may impede the work motivation of the respective employees (Exline and Bright, 2011). 


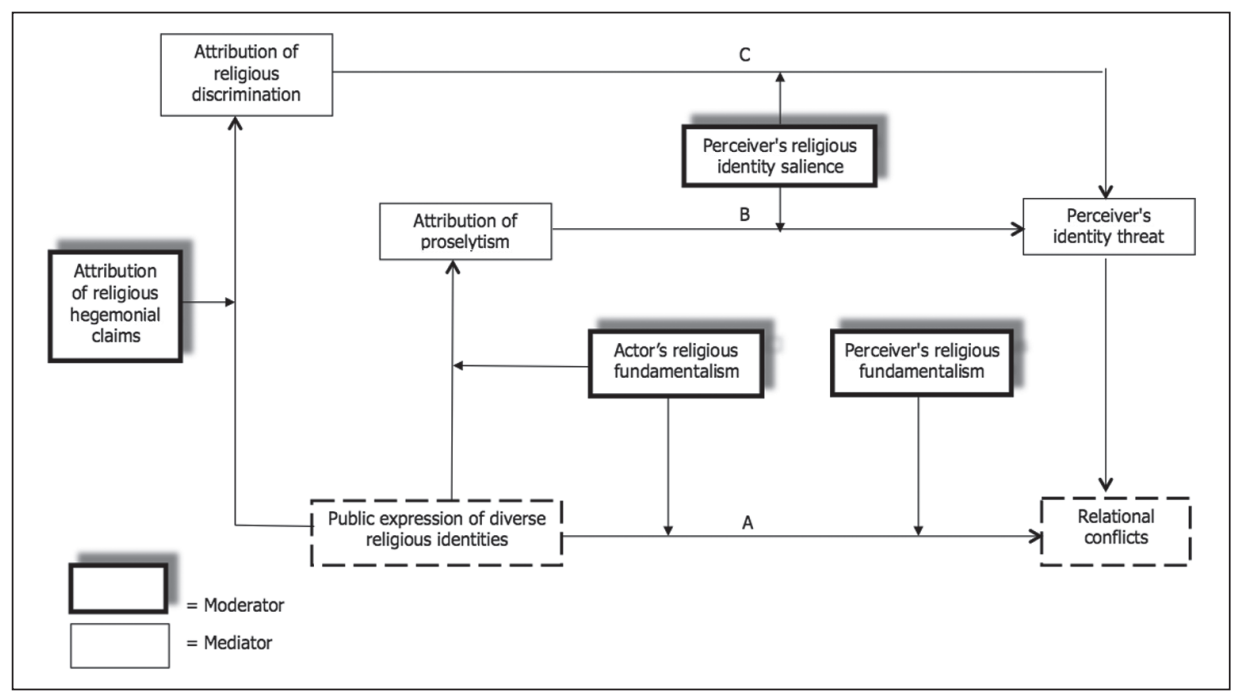

Figure I. Mediators and moderators of the relationship between the public expression of diverse religious identities and relational conflicts.

\section{Social context}

Each employee is not only a member of his or her organization, but also subscribes to a particular belief system (which could also be atheism or non-religion; see Table 1) within a certain society. Hence, societal factors can strongly influence interactions in organizations (Lopez et al., 2009). For example, Wuthnow (2007) found that 44 percent of Americans perceive Muslims as 'strange' and view them negatively. Outside of organizations, such negative views are fueled by simplified and emotionally charged TV reports (e.g. about forced marriages or brainwashing and weapons in madrassas, etc.) and numerous books, pamphlets, songs, films and cartoons denigrating or ridiculing Muslims as members of an out-group (Davidson, 2008). Muslims are a ready example in the post$9 / 11$ context. However, other religious groups experience similar dynamics to different degrees, most notably Jews (particularly the more orthodox), Evangelical Christians, Jehovah's Witnessess and Mormons (King et al., 2009). The view of other religions as 'strange,' which also underlies religiously motivated hate crimes (Davidson, 2008; Wuthnow, 2004), may become part of the collective consciousness within which organizational members interact with one another (Greenhouse, 2010).

\section{The public expression of diverse religious identities and relational conflicts}

Figure 1 summarizes our framework. We differentiate three paths (A, B, C) whereby the public expression of diverse religious identities can engender relational conflicts. We now examine these three paths in turn. 


\section{Path A: The public expression of diverse religious identities and relational conflicts}

The public expression of diverse religious identities makes the previously latent diversity concerning religious identities apparent. Through public expression, the deep-level attribute 'religious identity' becomes a surface-level attribute insofar as it sends cues and enables inferences regarding deep-level attributes of religious identity. Differences among different religious identities will be all the more striking the more the apparent differences not only pertain to basic and abstract beliefs, but also to concrete moral values and normative precepts and the more these are not described with regard to practical actions, but on the basis of official teachings. For example, liberal Protestants can cite the official teachings of their religion to be more active in promoting gender equality than are conservative Protestants (Roy, 2011). By contrast, some conservative Protestant denominations are more strongly engaged than are liberal Protestants in, for example, efforts to establish mandatory school prayer, deny rights to same-sex couples and prevent a liberalization of abortion and divorce laws (Cadge et al., 2007). In contrast to liberals, many conservative denominations are officially strongly opposed to the strict separation of church and state (Diamond, 1998).

If the previously latent diversity of religious identies becomes apparent, this can engender social categorization processes whereby persons are classified - depending upon actual and/or merely assumed similarities and dissimilarities - as either 'in-group' or 'out-group' members (Williams and O'Reilly, 1998). Specifically, members of the same religious identity (e.g. liberal Protestants) will form an in-group that regards members of other religious denominations (e.g. conservative Protestants) as being an 'outgroup.' The formation of in- and out-groups can subsequently engender intergroup bias - that is, in-group members are viewed and treated more favorably than out-group members (Brewer, 1999) - that is likely to result in relational conflicts (Williams and O'Reilly, 1998). Hence, we posit:

Proposition 1: The public expression of diverse religious identities is positively related to the probability of relational conflicts among members of different religious denominations.

\section{Religious fundamentalism as a moderator}

Perceivers' religious fundamentalism. Religious fundamentalism refers to the degree to which persons adhere to a dogmatic and intolerant way of being religious (Blogowska and Saroglou, 2011). For believers with high scores on religious fundamentalism, the existence of diverse religious identities per se constitutes a problem, because in their view there is only one 'true' religion. Therefore, high religious fundamentalism employees will be especially inclined to perceive actors who publicly express religious identities that differ from their own as fundamentally dissimilar. Under this condition, the likelihood will increase that the public expression of diverse religious identities engenders adverse social categorization processes. 
This process is exacerbated by the fact that religious fundamentalism is associated with two overlapping, but not identical attitudes (Mavor et al., 2011): conventionalism (defined as the rejection of individual deviance from the norm) and authoritarianism (defined as an aggressive stance in favor of national values and traditional morals (e.g. Mavor et al., 2011). This connection between religious fundamentalism and conventionalism and authoritarianism further increases the already pronounced tendency of these believers to stereotype and classify others (e.g. non-religious individuals) as out-group members (Harper, 2007; Johnson et al., 2011). Moreover, high religious fundamentalism and the social categorization processes it fosters often result in negative emotions toward out-group members, but positive emotions toward in-group members (Blogowska and Saroglou, 2011), which can further aggravate intergroup bias. Hence, we propose that if religious fundamentalism on the part of the perceivers is high, social categorization processes as well as intergroup bias are more likely to ensue. Therefore, if perceivers' religious fundamentalism is high, the public expression of diverse religious identities will be more closely related to relational conflicts.

By contrast, believers low in religious fundamentalism will at least tend to accept and be tolerant of the existence of multiple differing religious beliefs. These believers may even welcome the expression of diverse religious (and secular) identities as an opportunity for engaging in meaningful discussions, learning and growth (Watson and Morris, 2005). If religious fundamentalism is low, dissimilarities may thus hold some attraction. Similarities among members with different religious and secular identities are thus tied to the positive evaluation of diversity per se. By elevating the criteria for similarities and in-group inclusion to a meta-level, positive feelings and approach behaviors can ensue among the representatives of different social (religious and secular) identities. Under these circumstances, the positive potential entailed by the public expression of diverse religious identities is most likely to unfold. The appreciation of the perceived diversity can foster the willingness to communicate and cooperate among persons with different beliefs and help to end the stigmatization of some religious identities (Hicks, 2003; Ragins, 2008). Thus, given low religious fundamentalism and the above-discussed integrative mechanisms, the relationship between the public expression of diverse religious identities and relational conflicts is likely to be attenuated.

Actors' religious fundamentalism. Persons can publicly express their religious identity in different ways. If actors who express their religious identity score high on religious fundamentalism, they are likely to speak about their religious identity in ways that others perceive as closed-minded (Hunsberger and Jackson, 2005), one-sided and judgmental. Such perceptions are likely to foster attributions of dissimilarity, which in turn enhance social categorization processes and intergroup bias. As in the case of religious fundamentalism of perceivers, high religious fundamentalism of actors is therefore likely to strengthen the relationship between the public expression of religious identities and relational conflicts.

Hence we posit:

Proposition 2: The positive relationship between the public expression of diverse religious identities and relational conflicts among members of different religious denomination is moderated by both the actors' and the perceivers' religious fundamentalism such that this relationship is strengthened (weakened) when religious fundamentalism is high (low). 


\section{Path B: The public expression of diverse religious identities, the attribution of proselytism, identity threats and relational conflicts}

\section{The public expression of diverse religious identities and the attribution of proselytism}

We submit that the public expression of diverse religious identities is positively related to the attribution of proselytizing attempts on part of the perceivers. Given that even the actors themselves sometimes regard such a public expression in a secular organization as inappropriate (see Lips-Wiersma and Mills, 2002), perceivers are all the more likely to wonder why a co-worker has decided to express his or her religious identity. Of course, we do not regard the public expression of one's religious identity and proselytism as synonymous. Many believers may merely wish to express their religious identity to, for example, avoid identity gaps (e.g. Hicks, 2003). Others may wish to witness their beliefs. However, there is a thin line between witnessing and proselytizing - a line that is likely to be difficult to define and easy to blur even for the actors. From the perceiver's view, actors' witnessing becomes proselytizing if the receiver interprets the actor's witnessing as an attempt to convert the perceiver. Therefore, perceivers are likely to frequently (mis) interpret public expressions of religious identities. Moreover, there are denominations especially some Christian evangelicals (Hicks, 2003) - that are known for their strong proselytism efforts (Cash and Gray, 2000). Hence, the tendency on the part of perceivers to attribute proselytism to those who publicly express their religious identities seems plausible, regardless of whether or not this attribution is accurate in every case.

Actors can express their religious identity in a way that is perceived as tolerant and informative or in a way that is dogmatic and patronizing. Given that believers high on religious fundamentalism are convinced of the absolute validity of their religious identity (Hunsberger and Jackson, 2005), they will tend to express their religious identity in the latter, rather than the former, way (Blogowska and Saroglou, 2011). This decreases the uncertainty of the perceivers concerning whether or not to interpret the actor's public expression as proselytism by lending credence to attributions of proselytism. Hence, we posit:

Proposition 3: There is a positive relationship between actors' public expression of religious identity and perceivers' attribution of proselytizing attempts. This positive relationship is moderated by the actors' religious fundamentalism such that this relationship is strengthened (weakened) when actors' religious fundamentalism is high (low).

\section{Perceivers' attribution of proselytizing attempts, perceivers' identity threat and relational conflicts}

From the perspective of the perceiver, the attribution of proselytism means that the actor is trying to say that the perceivers' belief and value system has shortcomings and requires revisions or even fundamental changes. The actor may proselytize with positive intensions (guided by precepts such as the Christian 'love thy neighbor'). Nevertheless, 
perceivers can regard such efforts as an inappropriate critique of their religious or secular identity. If perceivers think that their religious or secular identity is not being respected, they will experience an identity threat, defined as potential harm to the value or the meaning of an (religious or secular) identity (Petriglieri, 2011). This is likely to happen when the positiveness or distinctiveness of one's identity is being questioned (Tajfel and Turner, 1986). (Attributed) proselytism may be experienced in this way and thus engender religious or secular identity threats. Moreover, we argue that the attribution of proselytism is more strongly related to identity threats when a perceiver's religious identity is highly salient (Petriglieri, 2011). As mentioned, high religious identity salience means that this part of a person's identity is central to the person's overall self-concept (Petriglieri, 2011). Hence, the more salient the religious identity is, the more strongly the attribution of proselytism insults, denigrates and threatens a perceiver's overall identity and self-concept (see Taylor, 1992). We therefore posit:

Proposition 4: Perceivers' attribution of proselytizing attempts is positively related to perceivers' experience of identity threats. Perceivers' religious (or secular) identity salience moderates this relationship such that it is strengthened (weakened) when perceivers' (religious) identity salience is high (low).

Furthermore, we argue that relational conflicts will develop between perceivers who believe their identity to be threatened and the actor whose public expression of his or her religious identity - interpreted by the perceiver as proselytism - engenders this identity threat. Hence, we posit that the perceivers' experience of identity threats fosters relational conflicts with the respective actors:

Proposition 5: Perceivers' experience of religious/secular identity threats is positively related to relational conflicts with the actors who are believed to be proselytizing.

\section{Path C: The public expression of diverse religious identities, the attribution of religious discrimination, identity threats and relational conflicts}

\section{The public expression of diverse religious identities and the attribution of religious discrimination}

Within most organizations, there will be religious majorities and minorities. The attribution of religious discrimination that we discuss next is most likely to be made by members of religious minorities and directed (openly or tacitly) against members of religious majorities. This attribution entails that minority members ascribe to majority members the intention to put religious minority members at a disadvantage with respect to the allocation of resources. Minority members may regard as evidence for such intentions the fact that numerous religious discrimination claims are regularly brought to the attention of the Equal Employment Commission (EEOC). In 2005 alone, the EEOC had to address 2340 claims of religious discrimination, one-third of which the EEOC evaluated as being justified (Davidson, 2008). Compared to age- or sex-related discrimination 
claims, this is a small number (Davidson, 2008). But religious discrimination claims roughly doubled in the years 1993-2003 (EEOC, 2004; Greenhouse, 2010). The EEOC gets claims related to differential treatment based on religion with respect to promotions, compensation, work assignments and employment terms (EEOC, 2010). These complaints are filed by members of many different religious groups, including Jews, Sikhs, Catholics, Protestants and Seventh Day Adventists. The greatest increase in the number of complaints has come from Muslims (Greenhouse, 2010).

At the theoretical level, the existence of religious status diversity has to be distinguished from its interpretation. Religious status diversity - that is, diversity as disparity (Harrison and Klein, 2007) - pertains to the degree to which important resources such as pay, power, status and prestige are distributed unequally across the different religious denominations in an organizational unit. At the societal level, there is some evidence for the existence of religious status diversity. With respect to criteria such as income, educational level and occupational prestige, members of some religions (e.g. mainline Presbyterians) on average seem to rank higher than members of other religions (e.g. Jehova's witnesses; Davidson, 2008; Smith and Faris, 2005; also see Beyer, 2003; Beyerlein and Chaves, 2003). The fact that a substantial number of religious discrimination claims appear to be justified (as evaluated by the EEOC) also suggests that religious status diversity exists.

The more diverse religious identities are expressed in public, the more the employees' different religious denominations become identifiable. Thus, religious status diversity in the organizational unit may become apparent. The problem with respect to religious discrimination is not the existence of religious status diversity as such, but the way it is interpreted. Members of religious minorities are unlikely to interpret the existence of religious status diversity as, for example, the result of religion-unrelated differences concerning qualifications and performance. Instead, it is more likely that religious minority members will interpret religious status diversity as a continuation of past experiences of discrimination and as the result of religious majority members' attempts to marginalize them still today (Beyerlein and Chaves, 2003; Davidson, 2008). These explanations of religious status diversity are continually fueled by individual cases that religious minority members may hear or read about. For example, there was a great deal of public discussion of the case of Susann Bashir, who was dismissed by her organization after she converted from Christianity to Islam (Gilliam, 2012). Moreover, Muslim women have reported that they feel they are being treated less favorably when they wear hijabs (a veil covering the head) during interviews (Ghumman and Jackson, 2010; Ghumman and Ryan, 2013).

Hence, we propose that the realization of the existence of religious status diversity combined with the explanation of this diversity as being the result of religious discrimination engenders a positive association between the public expression of diverse religious identities and the attribution of religious discrimination on the part of religious minority members against members of religious majorities in the respective organization.

Proposition 6: The public expression of diverse religious identities is positively related to religious minority members' attribution that religious majority members engage in acts of religious discrimination. 


\section{The attibution of religious hegemonial claims as moderator}

If many or all members of the religious majority express their religious identities in the workplace, members of religious minorities may interpret this as evidence of the majority's religious hegemonial claims. It is particularly likely that religious minority members will attribute religious hegemonial claims to majority members if, for example, the commencement of work in the morning is preceded by a joint prayer of the respective Christian majority (Domke, 2004). Beamon (2003) reported that not only members of non-Christian religions, but also many liberal Christians perceive such public rituals as indicative of religious hegemonial claims. Hence, we assume that religious status diversity made visible by the public expression of diverse religious identities is most likely to foster the attribution on the part of minority members that majority members discriminate against them if the minority members ascribe hegemonial claims to the majority members:

Proposition 7: The positive relationship between the public expression of diverse religious identities and the attribution of religious discrimination is moderated by minority members' attribution of religious hegemonial claims to members of religious majorities such that this relationship is strengthened (weakened) when the attribution of religious hegemonial claims is high (low).

\section{Attribution of religious discrimination, identity threats and relational conflicts}

Analogous to the dynamics described in Path B, minority members' attribution that religious majority members engage in acts of religious discrimination against them will lead the minority members to perceive their religious identity to be denigrated and to thus experience identity threats (Taylor, 1992). We further submit that, as on Path B, the relationship between minority members' attribution of religious discrimination and their experience of identity threats is positively moderated by the salience of their religious identity (Petriglieri, 2011):

Proposition 8: The attribution of religious discrimination is positively related to minority members' experience of identity threats. This relationship is moderated by minority members' religious identity salience such that this relationship is strengthened (weakened) when religious identity salience is high (low).

Finally, we posit that religious minority members' experience of identity threats will engender conflicts with religious majority members whom the minority members believe to engage in acts of religious discrimination against them. Religious minority members can actively cope with this religious identity threat (Petriglieri, 2011), for example by pronouncing a religious equality claim or by filing a religious discrimination claim at EEOC. However, such actions are likely to further exacerbate the conflicts between the respective members of religious minorities and majorities. Majorities tend to explicitly or implicitly expect minorities to assimilate to the dominating belief and value systems (Davidson, 2008; Verkuyten, 2005) - a position that minority members may interpret as 
authoritarian (Mavor et al., 2011). Moreover, there is the risk that these conflicts will foster intra-organizational disputes over the allocation of resources (Konrad, 2003). We therefore posit:

Proposition 9: Religious minority members' experience of identity threats is positively related to relational conflicts with respective religious majority members.

\section{Discussion}

The diversity literature has by and large neglected to examine the effects of religious diversity within organizational units (King et al., 2009). This constitutes a lamentable gap in the literature, given that religious diversity is rising in many countries and entails many challenges (Wuthnow, 2007). In light of the high levels of conflict among members of different religions at the societal level, we therefore agree with other authors (e.g. Exline and Bright, 2011) that it is necessary for scholars to fill the gap that exists in the literature concerning the effects of religious diversity within organizational units. By focussing on the US context, we developed a framework that examines the relationship between the public expression of diverse religious identities and relational conflicts among members of different religious affiliations, thereby responding to calls of diversity scholars (e.g. Jackson and Joshi, 2011) to develop more fine-grained and complex models that explore the effects of specific deep-level diversity attributes.

With respect to theory, by establishing the missing link (Stevens et al., 2008) between religious studies (e.g. Lynn et al., 2010) and identity-disclosure research (Ragins, 2008) on the one hand and management-oriented diversity research (e.g. Joshi and Roh, 2009) on the other, we identified important aspects with respect to which the deep-level diversity attribute religious identity differs from other deep-level diversity types. As discussed, with respect to the deep-level attribute religious identity, the question arises on the part of the perceivers why the actor reveals his or her deep-level religious identity. This question does not arise in regard to other deep-level attributes such as personality traits (e.g. extroversion) or task-related knowledge (Kearney et al., 2009). However, (tacitly) asking this question entails the risk of dysfunctional attributions (proselytism) that perceivers make in regard to actors' intentions. Hence, there are limitations associated with the trend in diversity research to treat as similar different forms of deep-level diversity and to develop generic models that are assumed to be generalizable to multiple diversity types (e.g. Van Knippenberg and Schippers, 2007). Whereas social categorization processes primarily ensue on the part of perceivers as a response to the content of the (surface-level) religious identity expressed by the actor, dysfunctional attributions of intentions are mainly the response to the (usually voluntary) expression of a deep-level attribute. This is a difference that has not been discussed adequately in the extant diversity literature.

The extant literature suggests that the public expression of diverse religious identities entails both opportunities and risks. Given that we have identified three partially independent paths whereby this public expression can engender relational conflicts, our framework primarily emphasizes the risks associated with employees expressing their religious identities in the workplace (see Exline and Bright, 2011). We believe that only 
a relatively complex framework such as the one we propose here enables an adequate understanding of these multi-faceted risks (Exline and Bright, 2011). These risks are further exacerbated by the discussed particularities of the social and legal context in the USA - environmental factors over which organizations have no influence (Davidson, 2008). Finally, and perhaps most importantly, religious fundamentalism plays a central role in our framework as a facilitator of relational conflicts. If religious fundamentalism is interpreted as a personality trait (see Altemeyer and Hunsberger, 1992), this factor is also not under the control of the organization, at least not with respect to the existing workforce. Hence, the positive potential afforded by a public expression of religious identities, valuable as it may be (Hicks, 2003), could prove difficult to realize.

\section{Limitations and further research}

One limitation of our analysis is that we partially relied on information that pertains to the societal level (e.g. Davidson, 2008). There is a need for much more descriptive data at the organizational level (King, 2008), especially because the degree of religious diversity in organizations is likely to be lower than that at the societal level due to organizational selection processes (Schneider et al., 1995). In addition to the moderators we discussed, it seems sensible to also analyze the (moderating) effects of the type of the organization (e.g. religious/non-religious; profit/non-profit; Smith et al., 2006), the size of the organization (Lynn et al., 2010) and the type of workplace - for example, in terms of the frequency of social interaction (Davidson and Caddell, 1994). In part because the effects of these moderators are controversial (Lynn et al., 2010), we did not refer to them in our analysis. Moreover, our framework would benefit from an analysis of the effects engendered by the changes in the religion-related workforce composition (e.g. a rising proportion of non-Christians and of employees with no religious affiliation).

As mentioned, some authors (e.g. Altemeyer and Hunsberger, 1992) have interpreted religious fundamentalism as a stable personality trait. Given the central importance of religious fundamentalism in our framework, it is important to consider if and to what extent religious fundamentalism - and the attendant authoritarianism (Mavor et al., 2011) - could also be construed as being the result of social norms (Mavor et al., 2011) that could be changed within organizations (Hicks, 2003).

\section{Managerial implications}

To strike an adequate balance between employees' need to express their religious identity, the legal requirements for reasonably accommodating them and the organization's interest to ensure constructive cooperation and positive work-related values presents an enormous management challenge. Implementing the meta-norm 'respectful pluralism' (Hicks, 2003: 174; also see Gentile, 2011) may be helpful. Respectful pluralism refers to the requirement that all employees be mutually respectful in their relations with others, including those who express religious identities that differ from their own. This metanorm could be communicated to employees in diversity trainings (King EB et al., 2010). As mentioned, in this process it may be helpful to train actors in how to express their religious identities and perceivers in how to interpret actors' expression of religious 
identities. Accurate information about the meaning of such things as sacred holidays, rituals, practices or attire can be explained for various faiths, thus reducing confusion about the implications of different beliefs. Moreover, defining general diversity-related guidelines may be helpful. On the one hand, these guidelines should emphasize the right of all employees to express their religious or secular identity within the confines of the existing rules. On the other hand, these guidelines should emphasize the obligation of all employees to respect the right of all colleagues to do the same.

Implementing these diversity-related guidelines will inevitably require compromises. Research on procedural fairness (e.g. Cropanzano and Stein, 2009) can help managers take informed steps toward developing generally accepted guidelines. The concept of procedural fairness mandates that such guidelines are defined collaboratively and with equal involvement of both religious majority and religious minority members.

Our framework demonstrates the risks associated with a tolerant and pluralistic organizational culture (Gebert and Boerner, 1999; Hicks, 2003; Taylor, 1992) within which diversity is positively viewed as a reflection of norms concerning tolerance and pluralism (Wuthnow, 2007). The more the potentially conflict-inducing public expression of diverse religious identities is permitted, the more the organizational unit would have to implement consensus-inducing measures such as fostering a superordinate common social identity (Fiol et al., 2009; Gebert et al., 2010), partially based on the metanorm of 'respectful pluralism' (Hicks, 2003). Instead of one-sidedly emphasizing the ideas of tolerance and individual self-expression, it would be important to simultaneously communicate their necessary limitation (Hicks, 2003; Taylor, 1992) and emphasize justice for all (Cropanzano and Stein, 2009; Stevens et al., 2008). This will increase the chance that the diversity-related guidelines regarding the public expression of diverse religious identities would be accepted and acted upon.

\section{Acknowledgements}

We thank Associate Editor Mike Noon and three anonymous reviewers for their highly constructive feedback that greatly improved the quality of this article.

\section{Funding}

This study was supported by National Natural Science Foundation of China (grant numbers 70972128 and 71072142 ).

\section{References}

Altemeyer B and Hunsberger B (1992) Authoritarianism, religious fundamentalism, quest, and prejudice. The International Journal for the Psychology of Religion 2(2): 113-133.

American Religious Identification Survey (ARIS) (2008) Available at: http://www.census.gov/ compendia/stabab/cats/population/religion.html (accessed 14 November 2012).

Beaman LG (2003) The myth of pluralism, diversity and vigor: The constitutional privilege of protestantism in the United States and Canada. Journal for the Scientific Study of Religion 42(3): 311-325.

Beyer P (2003) Constitutional privilege and constituting pluralism: Religious freedom in national, global, and legal context. Journal for the Scientific Study of Religion 42(3): 333-339. 
Beyerlein K and Chaves M (2003) The political activities of religious congregations in the United States. Journal for the Scientific Study of Religion 42(2): 229-246.

Blogowska J and Saroglou V (2011) Religious fundamentalism and limited prosociality as a function of target. Journal for the Scientific Study of Religion 50(1): 44-60.

Brewer MB (1999) The psychology of prejudice: Ingroup love or outgroup hate? Journal of Social Issues 55(3): 429-444.

Cadge W, Day H and Wildeman C (2007) Bridging the denomination-congregation divide: Evangelical Lutheran Church in America congregations respond to homosexuality. Review of Religious Research 48(3): 245-259.

Cash KC and Gray GR (2000) A framework for accommodating religion and spirituality in the workplace. Academy of Management Executive 14(3): 124-133.

Chaves M (2010) Rain dances in the dry session: Overcoming the religious congruence fallacy. Journal for the Scientific Study of Religion 49(1): 1-14.

Clair JA, Beatty JR and Maclean TL (2005) Out of sight but not out of mind: Managing invisible social identities in the workplace. Academy of Management Review 30(1): 78-95.

Cropanzano R and Stein JH (2009) Organizational justice and behavioral ethics: Promises and prospects. Business Ethics Quarterly 19(2):193-223.

Davidson JC and Caddell DP (1994) Religion and the meaning of work. Journal of the Scientific Study of Religion 33(2): 135-147.

Davidson JD (2008) Religious stratification: Origins, persistence, and consequences. Sociology of Religion 69(4): 371-395.

De Wit FRC, Greer LL and Jehn KA (2012) The paradox of intragroup conflict: A meta-analysis. Journal of Applied Psychology 97(2): 360-390.

Diamond S (1998) Not By Politics Alone. The Enduring Influence of the Christian Right. New York: Wiley.

Domke D (2004) God Willing? Political Fundamentalism in the White House, the 'War on Terror, ' and the Echoing Press. London: Pluto Press.

Equal Employment Opportunity Commission (2004) Religion based charges. FY 1992-FY 2003.

Equal Employment Opportunity Commision (2010) EEOC v. JBS USA,LLCd/b/a JBS Swift \& Company,8:10-cv-00318-TDT(D.Neb. Available at: http://www.eeoc.gov.eeoc/newsroom/ release/8-31-10.cfm. (accessed 10 November 2012).

Exline J and Bright DS (2011) Spiritual and religious struggles in the workplace. Journal of Management, Spirituality and Religion 8(2): 123-142.

Fiol CM, Pratt MG and O'Connor EJ (2009) Managing intractable identity conflicts. Academy of Management Review 34(1): 32-55.

Gebert D and Boerner S (1999) The open and the closed corporation as conflicting forms of organization. The Journal of Applied Behavioral Science 35(3): 341-359.

Gebert D, Boerner S and Kearney E (2010) Fostering team innovation: Why is it important to combine opposing action strategies? Organization Science 21(3): 593-608.

Gentile MC (2011) A faculty forum on giving voice to values: Faculty perspectives on the uses of the pedagogy and curriculum for value-driven leadership. Journal of Business Ethic Education 8(1): 305-307.

Ghumman S and Jackson L (2010) The downside of religious attire: The Muslim headscarf and expectations of obtaining employment. Journal of Organizational Behavior 31(1): 4-23.

Ghumman S and Ryan AM (2013) Not welcome here: Discrimination towards women who wear the Muslim headscarf. Human Relations 66(5): 671-698.

Gilliam C (2012) Muslim women convert, wins $\$ 5$ million verdict from at\&t for discrimination. Available at: http://www.huffingtonpost.com/2012/05/05/muslim-woman-wins-5-millionatt_n_1479884.html (accessed 10 November 2012). 
Greenhouse S (2010) Muslims report rising discriminations at work. The New York Times, 23 September. Available at: http://www.nytimes.com/2010/09/24/business/24muslim.html? pagewanted=all\&_r $=0$.

Gregory RF (2011) Encounering Religion in the Workplace: The Legal Rights and Responsibilities of Workers and Employees. Ithaca, NY: Cornell University Press.

Harper M (2007) The stereotyping of non-religious people by religious students. Journal for the Scientific Study of Religion 46(4): 539-552.

Harrison DA and Klein KJ (2007) What's the difference? Diversity constructs as separation, variety, or disparity in organizations. Academy of Management Review 32(4): 1199-1228.

Harrison DA, Price KH and Bell MP (1998) Beyond relational demography: Time and the effects of surface- and deep-level diversity on work group cohesion. Academy of Management Journal 41(1): 96-107.

Hicks DA (2003) Religion and the Work Place - Pluralism, Spirituality, Leadership. Cambridge: Cambridge University Press

Hill PC, Pargament KI, Wood RW, Mccullough ME, Swayers JP, Larson DB and Zinnbauer BJ (2000) Conceptualizing religion and spirituality: Points of commonality, points of departure. Journal for the Theory of Social Behavior 30(1): 51-77.

Humphrey SE, Hollenbeck JR, Meyer CJ and Ilgen DR (2007) Trait configurations in self-managed teams: A conceptual examination of the use of seeding for maximizing and minimizing trait variance in teams. Journal of Applied Psychology 92(3): 885-892.

Hunsberger B and Jackson LM (2005) Religion, meaning, and prejudice. Journal of Social Issues 61(4): 807-826.

Jackson SE and Joshi A (2011) Work team diversity. In: Zedeck S (ed.) APA Handbook of Industrial and Organizational Psychology, Vol. 1. Washington, DC: American Psychological Association Press, 651-686.

Jehn KA and Bendersky C (2003) Intragroup conflict in organizations: A contingency perspective on the conflict-outcome relationship. In: Staw B (ed.) Research in Organizational Behavior, Vol. 25. Greenwich, CT: JAI Press, 187-242.

Johnson MK, Rowatt WC, Barnak-Brak LM, Patock-Peckham JA, LaBouff JP and Carlisle RD (2011) A mediational analysis of the role of right-wing authoritarianism and religious fundamentalism in the religiosity-prejudice link. Personality and Individual Differences 50(6): 851-856.

Joshi A and Roh H (2009) The role of context in work team diversity research. Academy of Management Journal 52(3): 599-627.

Kearney E, Gebert D and Voelpel S (2009) When and how diversity benefits teams: The importance of team members' need for cognition. Academy of Management Journal 52(3): 581-598.

King EB, Gulick LMV and Avery DR (2010) The divide between diversity training and diversity education: Integrating best practices. Journal of Management Education 34(6): 891-906.

King JE (2008) (Dis)Missing the obvious: Will mainstream management research ever take religion seriously? Journal of Management Inquiry 17(3): 214-224.

King JE, Bell MP and Lawrence E (2009) Religion as an aspect of work place diversity: An examination of the U.S. context and a call for international research. Journal of Management, Spirituality and Religion 6(1): 43-57.

King JE, Stewart MM and McKay PM (2010) Religiosity, religious identity, and bias towards workplace others. Academy of Management Proceedings, August.

Konrad AM (2003) Defining the domain of workplace diversity scholarship. Group and Organization Management 28(1): 4-17.

Lips-Wiersma M and Mills C (2002) Coming out of the closet: Negotiating spiritual expression in the workplace. Journal of Managerial Psychology 17(3): 183-202. 
Lopez LH, Ramos RR and Ramos SR (2009) Spiritual behaviour in the workplace as a topic of research. Journal of Management, Spirituality and Religion 6(4): 273-285.

Lynn LM, Naughton MJ and Veen SV (2010) Connecting religion and work: Patterns and influence of work-faith integration. Human Relations 64(5): 675-701.

Mavor KI, Lathe B and Louis WR (2011) Religion, prejudice, and authoritarianism: Is RWA a boon or bane to the psychology of religion? Journal for the scientific study of religion 50(1): $22-43$.

Miller DW (2003) The faith at work movement. Theology Today 60(3): 301-310.

Miller DW (2007) God at Work: The History and Promise of the Faith at Work Movement. Oxford: Oxford University Press.

Mitroff II and Denton EA (1999) A study of spirituality in the work place. Sloan Management Review 40(4): 83-92.

Morgan JF (2005) Religion at work: A legal quagmire. Managerial Law 47(3-4): 247-259.

Petriglieri JL (2011) Under threat: Responses to and the consequences of threats to individual identities. Academy of Management Review 36(4): 641-662.

Ragins BR (2008) Disclosure disconnects: Antecedents and consequences of disclosing invisible stigmas across life domains. Academy of Management Review 33(1): 194-215.

Ross L (1977) The intuitive psychologist and his shortcomings: Distortions in the attribution process. In: Berkowitz L (ed.) Advances in Experimental Social Psychology, Vol. 10. New York: Academic Press, 173-220.

Roy O (2011) Heilige Einfalt. Frankfurt: Pantheon.

Schneider B, Goldstein HW and Smith DB (1995) The ASA framework: An update. Personnel Psychology 48(4): 747-773.

Smith C and Faris R (2005) Socioeconomic inequality in the American religious system: An update and assessment. Journal for the Scientific Study of Religion 44(1): 95-104.

Smith J, Arendt C and Lahman J (2006) Framing the work of art: Spirituality and the career discourse in the nonprofit arts sector. Communication Studies 57(1): 25-46.

Stark R and Glock CY (2008) The 'new denominationalism'. Review of Religious Research 50 (special issue): $33-42$.

Stevens GF, Plaut VC and Sanchez-Burks J (2008) Unlocking the benefits of diversity: All-inclusive multiculturalism and positive organizational change. The Journal of Applied Behavioral Science 44(1): 116-133.

Tajfel H and Turner JC (1986) The social identity theory of intergroup behavior. In: Worchel S and Austin WG (eds) Psychology of Intergroup Relations. Chicago, IL: Nelson-Hall, 7-24.

Taylor C (1992) Multiculturalism and the Politics of Recognition. New York: Princeton University Press.

Van Knippenberg D and Schippers MC (2007) Work group diversity. Annual Review of Psychology 58: 515-541.

Verkuyten M (2005) Ethnic group identification and group evaluation among minority and majority groups: Testing the multiculturalism hypothesis. Journal of Personality and Social Psychology 88(1): 121-138.

Watson PJ and Morris RJ (2005) Spiritual Experience Index and identity: Relationships with religious orientation, religious interest, and intolerance of ambiguity. Review of Religious Research 46(4): 371-379.

Weaver GR and Agle B (2002) Religiosity and ethical behavior in organizations: A symbolic interactionist perspective. Academy of Management Review 27(1): 77-97.

Williams K and O'Reilly C (1998) Demography and diversity in organizations: A review of forty years of research. In: Sutton RI and Staw BM (eds) Research in Organizational Behavior, Vol. 20. Greenwich, CT: JAI Press, 77-140. 
Wuthnow R (2004) Presidential address: The challenge of diversity. Journal for the Scientific Study of Religion 43(2): 159-170.

Wuthnow R (2007) America and the Challenges of Religious Diversity. New York: Princeton University Press.

Diether Gebert is Visiting Professor at the Department of Organization and Human Resource Management, Business School, Renmin University of China. He retired as Professor for Leadership and Human Resource Management at the Technical University of Berlin, Germany, in 2005. His research interests include diversity, team innovation, leadership and change management. His work has been published in journals such as Academy of Management Journal, Journal of Applied Psychology and Organization Science. [Email: diether.gebert@tu-berlin.de]

Sabine Boerner, Professor at the University of Konstanz, Germany, received her diploma in business administration from the University of Bayreuth, Germany in 1991. She has held the chair of 'Management, especially Strategy and Leadership' at the University of Konstanz since 2004. Her main research focus is on leadership, the management of teams and the management of cultural industries. Her work has been published in journals including Journal of Applied Psychology, Organization Science and British Journal of Management. [Email: Sabine.Boerner@uni-konstanz.de]

Eric Kearney is Professor of Organizational Behavior and Human Resource Management at Leibniz Universität Hannover, Germany. His research interests include leadership, team composition, team effectiveness and innovation. His work has been published in journals such as Academy of Management Journal, Journal of Applied Psychology, Organizational Research Methods, Organization Science and Journal of Occupational and Organizational Psychology. [Email: kearney@wiwi.uni-hannover.de]

James E King Jr is Associate Professor of Management at the University of Alabama, USA. His research interests include faith at work, diversity and work/life conflict. His work has been published in Journal of Management Inquiry, Academy of Management Learning and Education Journal, Journal of Vocational Behavior and Journal of Management, Spirituality and Religion, among others. [Email: jking@cba.ua.edu]

Kai Zhang is Professor of Organizational Behavior and Chair of Organization and Human Resource Department at School of Business at Renmin University of China. He also worked as a visiting scholar at University of Washington in USA and McMaster University in Canada. His areas of expertise include complexity and behavioral dynamics, leadership theory, goal theory and creative thinking. He received the Academy of Management Organizational Behavior Division Best Paper Award twice, in 2006 and 2010 respectively. He and his co-authors also won the Best Paper Award from the Administrative Science Association of Canada in 2009. He worked as a consultant at the Personnel Department of Beijing Organizing Committee for the 29th Olympic Games in 2003 and 2004. Now, he acts as Representative-at-large for Mainland China of International Association of Chinese Management Research (IACMR). [Email: zhangkai@ruc.edu.cn]

Lynda Jiwen Song is Associate Professor in Management and Vice Department Chair at the Department of Organization and Human Resource Management, Business School, Renmin University of China. Her research and teaching interests include organizational culture, leadership, employment relationship, creativity, emotional intelligence, diversity and cross-cultural studies. Her research has appeared in Administrative Science Quarterly, Journal of Applied Psychology, Journal of International Business Studies, Human Resource Management, Journal of Management, Management and Organization Review, International Journal of Human Resource Management and Frontiers of Business Research in China. [Email: songjiwen@gmail.com] 